\title{
Behavioral Study on the Gracile Axonal Dystrophy (GAD) Mutant Mouse
}

\author{
Kazuto YAMAZAKI, Takahiro NAKAZAWA, Manabu MATSUNAGA, \\ Akira KUMAZAWA, Takeru KANEKO, and Tsuneo WAKABAYASHI
}

Tsukuba Research Laboratories, Eisai Co., Ltd., 5-1-3

Tokodai, Tsukuba-shi, Ibaraki 300-26, Japan

(Received 21 February 1992/Accepted 13 May 1992)

\begin{abstract}
We investigated motor function and pain sensation in the gracile axonal dystrophy (GAD) mutant mouse, using the tail-flick test and the rotarod test. GAD (gad/gad) and normal sib mice $(\mathrm{gad} /+$ or $+/+)$ were used between 5 and 11 weeks of age, during which time the behavioral signs of GAD mice shifted from sensory ataxia (about 4 to 8 weeks of age) to paresis (after about 9 weeks of age). In the tail-flick test, significant shortening of latency was observed at 6 and 8 weeks of age in female GAD mice, in comparison with normal female mice. This may be related to dysfunction or degeneration of axons in the fasciculus gracilis, whose collaterals are thought to control the transmission of nociceptive information. In the rotarod test, a cumulative $\chi^{2}$ test showed significant reduction in the performance times of GAD mice beginning at 5 and 6 weeks of age in males and females, respectively, indicating that the rotarod test can detect the development of motor incoordination as early as these ages. The performance times of GAD mice dropped sharply from 9 weeks of age onwards, and this is believed to reflect the progression of paresis. The rotarod test therefore appears to be a good method of quantifying behavioral changes in GAD mice and to be applicable both to objective selection of GAD mice before 8 weeks of age and to evaluation of drugs to treat ataxia or paresis. - KEY WORDS : gracile axonal dystrophy mouse, motor function, rotarod test
\end{abstract}

Gracile axonal dystrophy (GAD) is a neurological autosomal recessive mutant mouse with the gene symbol, gad [10]. The mutants were first discovered because of the animals' ataxic gait and dragging of the hindlimbs beginning at about 11 weeks of age. Thereafter, the disease progressed gradually, causing muscular atrophy of the hindlimbs, and the mutants died between 7 and 9 months of age. Although the mutants appeared normal in their cage until about 11 weeks of age, detailed clinical observations showed that the mutants ( $\mathrm{gad} / \mathrm{gad}$ ) can be distinguished from normal littermates $(\mathrm{gad} /+$ or $+/+)$ as early as 4 weeks of age by the position of the hindlimbs when suspended by the tail. When this is done, GAD mice stretch their hindlimbs upward spasmodically and/or clasp them tightly together [10].

Pathologically, in the central nervous system the dorsal column, the dorsal spinocerebellar, pyramidal, and spinal trigeminal tracts are affectted $[4,6,10,11]$. Focally swollen axons or spheroids, which are characteristic of GAD mice, are observed in these affected tracts in addition to nerve fiber loss and gliosis. The fasciculus gracilis of the dorsal column, one of the ascending sensory pathways, is the tract which degenerates first and most severely. In the peripheral nervous system, both sensory and motor nerves are affected $[7,8]$. Beginning at about 3 weeks of age, the 
Table 1. Changes in mean tail-flick latencies \pm S. E. M. (sec) of male and female GAD and phenotypically normal sib mice from 6 to 11 weeks of age

\begin{tabular}{lcccc}
\hline \multirow{2}{*}{ Sex } & \multirow{2}{*}{$\begin{array}{c}\text { Age } \\
\text { (weeks) }\end{array}$} & \multicolumn{3}{c}{ Phenotype } \\
\cline { 3 - 5 } Male & & & GAD & Normal \\
& 6 & $6.6 \pm 0.8(11)^{1)}$ & $6.4 \pm 0.5(11)$ \\
& 7 & $6.9 \pm 1.2(11)$ & $5.4 \pm 0.5(11)$ \\
& 8 & $5.4 \pm 0.8(11)$ & $5.1 \pm 0.4(11)$ \\
& 9 & $4.3 \pm 0.6(11)$ & $5.0 \pm 0.8(11)$ \\
& 11 & $5.0 \pm 0.5(11)$ & $5.6 \pm 0.9(11)$ \\
\hline \multirow{2}{*}{ Female } & & & & \\
& 6 & $5.2 \pm 0.6(10)$ & $8.3 \pm 1.2(10)^{*}$ \\
& 7 & $4.5 \pm 0.4(10)$ & $5.8 \pm 0.6(10)$ \\
& 8 & $4.6 \pm 0.6(10)$ & $7.0 \pm 0.9(10)^{*}$ \\
& 9 & $4.2 \pm 0.3(10)$ & $4.8 \pm 0.5(10)$ \\
& 11 & $4.7 \pm 0.5(10)$ & $6.5 \pm 0.9(9)$ \\
\hline
\end{tabular}

1) Number of mice tested. Asterisks indicate significant differences at $\mathrm{P}<0.05$ between $\mathrm{GAD}$ and age-matched normal sib mice according to Student's t-test.

Table 2. Changes in the distribution of GAD and phenotypically normal sib mice according to their rotarod performance times from 5 to 11 weeks of age

\begin{tabular}{|c|c|c|c|c|c|c|c|c|c|c|c|c|}
\hline \multirow{2}{*}{ Sex } & \multirow{2}{*}{$\begin{array}{c}\text { Age } \\
\text { (weeks) }\end{array}$} & \multicolumn{5}{|c|}{ GAD } & \multicolumn{6}{|c|}{ Normal } \\
\hline & & $\mathrm{N}$ & $0-19$ & $20-39$ & $40-59$ & $60(\mathrm{sec})$ & $\mathrm{N}$ & $0-19$ & $20-39$ & $40-59$ & 60 & (sec) \\
\hline \multicolumn{13}{|c|}{ Male } \\
\hline & 5 & 10 & 1 & 1 & 2 & 6 & 10 & 0 & 0 & 0 & 10 & $*$ \\
\hline & 6 & 14 & 2 & 5 & 2 & 5 & 14 & 0 & 0 & 2 & 12 & ** \\
\hline & 7 & 14 & 1 & 3 & 2 & 8 & 14 & 0 & 0 & 0 & 14 & ** \\
\hline & 8 & 14 & 2 & 0 & 1 & 11 & 14 & 0 & 0 & 1 & 13 & \\
\hline & 9 & 14 & 3 & 5 & 3 & 3 & 14 & 0 & 0 & 0 & 14 & ** \\
\hline & 10 & 14 & 8 & 3 & 2 & 1 & 14 & 0 & 0 & 0 & 14 & $* *$ \\
\hline & 11 & 14 & 13 & 0 & 0 & 1 & 14 & 0 & 0 & 0 & 14 & ** \\
\hline
\end{tabular}

Female

\begin{tabular}{rrrrrrrrrrrr}
5 & 4 & 1 & 0 & 1 & 2 & 4 & 0 & 0 & 0 & 4 & $* *$ \\
6 & 10 & 2 & 2 & 1 & 5 & 10 & 0 & 0 & 1 & 9 & $* *$ \\
7 & 10 & 0 & 2 & 3 & 5 & 10 & 0 & 0 & 0 & 10 & $* *$ \\
8 & 10 & 1 & 1 & 1 & 7 & 10 & 0 & 0 & 0 & 10 & $*$ \\
9 & 10 & 1 & 5 & 1 & 3 & 10 & 0 & 0 & 0 & 10 & $* *$ \\
10 & 10 & 2 & 5 & 2 & 1 & 10 & 0 & 0 & 0 & 10 & $* *$ \\
11 & 10 & 7 & 2 & 1 & 0 & 10 & 0 & 0 & 1 & 9 & $* *$ \\
\hline
\end{tabular}

Asterisks indicate significant differences between GAD and age-matched normal sib mice according to the cumulative $x^{2}$ test ${ }^{*} \mathrm{P}<0.05^{* *} \mathrm{P}<0.01$

sensory nerve fibers in the muscle spindles degenerate starting at their distal end, while the motor nerves begin to degenerate from their endplates at about 8 weeks of age. Axonal degeneration in GAD mice occurs in the preterminal or presynaptic parts of axons and progresses toward the cell bodies, the socalled "dying back" phenomenon. Based on these 
clinical and pathological findings, we can divide the clinical course in GAD mouse into two phases : 1) a sensory ataxia stage between about 4 and 8 weeks of age, and 2) a paresis stage after about 9 weeks of age [7]. We believe that GAD mice can serve as an animal model for spinocerebellar degeneration (ataxia), particularly Friedreich's ataxia, and CharcotMarie-Tooth disease (hereditary motor and sensory neuropathy) in humans $[4,7,11]$.

Since there have been few quantitative studies on behavior or pain sensation in the GAD mouse, we tried to measure both, using two methods. The main purpose of the present study was : 1) to find (a) good behavioral method(s) of quantifying and characterizing the motor incoordination or abnormal sensation of the GAD mouse, particurlarly between 6 and 11 weeks of age when the clinical signs change qualitatively, and 2) to compare the behavioral data obtained with pathological changes.

The animals used were GAD ( $\mathrm{gad} / \mathrm{gad}$ ) mutant mice and phenotypically normal littermates $(\mathrm{gad} /+$ or $+/+)$ from a C57BL/6-gad (B 6-gad) congenic strain. The B 6-gad strain, originally introduced from the Laboratory of Animal Genetics, Faculty of Agricultural Sciences, Nagoya University, Japan, was maintained at Tsukuba Research Laboratories, Eisai Co., Ltd., Ibaraki, Japan. Mating procedures to maintain the strain and to produce the mice have been described previously [9] . The mice were provided with a commercial diet (CE-2, Nihon CLEA Inc., Tokyo, Japan) and water ad libitum under controlled temperature, humidity, and light conditions $\left(22 \pm 2{ }^{\circ} \mathrm{C}, 55 \pm\right.$ $5 \%$, and a 12-hr light/dark cycle with the lights on at $07: 00$ ).

The tail-flick test was conducted between $09: 00$ and $10: 00$ in order to investigate nociception in GAD mice by the method of D'Amour and Smith [2], recording the tailflick latency. The instrument (IITC Inc., N. J., U. S. A.) was adjusted as follows : sensitivi$t y=3.0$; beam $=85$. To minimize tissue damage, we set the cutoff time at $15 \mathrm{sec}$, and cooled the tail in tap water after measurement.

We used the rotarod test [3] to quantify motor incoordination in GAD mice, conducting it between $10: 00$ and $12: 00$. The mice were trained and accustomed to movement on a rotarod at beginning weeks of age in the experiment. The rotarod apparatus (Natsume Seisakusho Co., Ltd., Tokyo, Japan) was set at 10 rotations per min. The time taken for each mouse to fall from the rotarod was recorded. Measurements were made three times for each mouce, and the longest time was recorded. The cutoff time was set at $60 \mathrm{sec}$.

Comparison between GAD and agematched normal sib mice in the tail-flick test was made using the $\mathrm{F}$-test followed by Student's $\mathrm{t}$-test (when $\mathrm{P} \geqq 0.05$ in the $\mathrm{F}$-test) or Aspin-Welch's test (when $\mathrm{P}<0.05$ in the $\mathrm{F}$-test). In the rotarod test, the comparisons were made using the cumulative $\chi^{2}$ test. $P$ values less than 0.05 were considered to represent significant differences.

Table 1 shows the mean tail-flick latencies of GAD and normal mice from 6 to 11 weeks of age. No prolongation of the latencies was observed at any age in either sex, suggesting that $\mathrm{C}$ fibers, which are excited by thermal stimuli [1], escape degeneration. Rather than prolongation, slight but significant shortening of the latencies was seen in female GAD mice aged 6 and 8 weeks $(P<0.05)$. According to the gate control theory proposed by Melzack and Wall $[5,12]$, the transmission of pain messages at spinal relays is controlled by collaterals of primary afferent fibers in the dorsal column passing into the gray matter. The theory was corroborated by the fact that inhibition of pain was obtained by dorsal column stimulation [1]. The fasciculus gracilis of the dorsal column degenerates first and most severely in GAD mice, beginning at about 4 weeks of age. Moreover, spheroids are observed in the gray matter of the lumbar cord particularly the dorsal part, where $\mathrm{A} \delta$ and $\mathrm{C}$ fibers terminate [1], from about 11 of weeks age onwards [4]. The reduction in latencies may be related to dysfunction or degeneration of collaterals of primary afferents controlling the transmission of nociceptive information in the fasciculus gracilis.

Table 2 shows changes in the distribution of GAD and normal mice with regard to their performance times in the rotarod test from 5 to 11 weeks of age. Throughout this testing period phenotypically normal mice remained on the rotarod beyond the cutoff time of 60 sec. The five exceptions were $48 \mathrm{sec}(2$ mice) and $59 \mathrm{sec}$ in the males and $49 \mathrm{sec}$ and $59 \mathrm{sec}$ in the females. 
At 5 weeks of age, GAD mice whose performance times were under $40 \mathrm{sec}(21.4 \% ; 2$ of the 10 males and 1 of the 4 females) first appeared. Reportedly, many spheroids appear in the gracile nucleus of the medulla oblongata, and sensory nerve terminals in the muscle spindles degenerate at 3 to 4 weeks of age $[7$, 8]. Thus,clinically, sensory ataxia occurs at about 5 weeks of age. Hence, the rotarod test can detect the development of motor incoordination insome GAD mice at 5 weeks of age as a decrease in the performance time.

Statistically significant differences between GAD and normal littermates were detected using the cumulative $\chi^{2}$ test beginning at 5 and 6 weeks of age in males and females, respectively (Table 2). At 8 weeks of age, there was an increase in the number of GAD mice whose performance times were over $60 \mathrm{sec}$. As a result, the significant differences disappeared in the males, and the $P$ value increased $(P<0.01$ to $P<0.05)$ in the females in the cumulative $\chi^{2}$ test. This phenomenon may be explained by the following hypotheses:1) GAD mice can become accustomed to walking on the rotarod, or 2) sensory ataxia is slightly ameliorated by regeneration of sensory fibers in muscle spindles following their degeneration $[7,8]$.

Significant difference again appeared in males and the $P$ value decreased $(P<0.05$ to $P<0.01)$ in females at 9 weeks of age, after which the performance times dropped sharply, especially in male mice (Table 2 ). At 11 weeks of age, almost all GAD mice $(91.7 \% ; 13$ of the 14 males and 9 of the 10 females) had performance times of less than $40 \mathrm{sec}$. The age when performance times begin to decrease almost perfectly coincides with the age at which the motor nerves start to degenerate from their terminals, i.e., from the motor endplates, in the hindlimbs [7]. Because of this denervation, grouped muscle fiber atrophy and paresis occur, resulting in difficulty in moving. Thus, a sharp drop in performance time can be caused by both concurrent motor dysfnction and paresis.

GAD mice clearly exhibit tremor and abnormal gait, dragging their hindlimbs, after about 11 weeks of age. One can thus distinguish between GAD and normal mice after this age. Before about 8 weeks of age, however, one cannot select GAD mice without some degree of experience in distinguishing them by suspending mice by the tail. Under the rotarod test conditions in this study, the rotarod performance times of almost all normal mice were over $60 \mathrm{sec}$, and the times were within 48 to $59 \mathrm{sec}$ even in the case of the 5 exceptions. Accordingly, mice whose performance times are less than $40 \mathrm{sec}$ must be GAD mice, and the rotarod test can be used to select GAD mice before 8 weeks of age more objectively than by suspending them by the tail. Moreover, the test can serve as a good method of evaluating drug candidates for the treatment of ataxia or paresis.

We are indebted to Prof. Dr. T. Tomita, Laboratory of Animal Genetics, School of Agricultural Sciences, Nagoya University, for the generous introduction of the B 6- gad strain into our Laboratories.

\section{References}

[1] Besson, J. M. and Chaouch, A. (1987). Physiol Rev., 67, 67-186.

[2] D'Amour, F. E. and Smith, D. L. (1941). J. Pharmacol Exp. Ther., 72, 74-79.

[3] Dunham, N. W. and Miya, T. S. (1957). J. Am Phar. Ass, 46, 208-209.

[4] Kikuchi, T., Mukoyama, M., Yamazaki, K., and Moriya, H. (1990). Acta Neuropathol, 80, 145-151.

[5] Melzack, R. and Wall, P. D. (1965). Science, 150, 971-979.

[6] Mukoyama, M., Yamazaki, K., Kikuchi, T., and Tomita, T. (1989). Acta Neuropathol, 79, 294-299.

[ 7 ] Oda, K., Yamazaki, K., Miura, H., Endo, C., Shibasaki, H., T., and Kikuchi, T. (1991). Advances in Neurological Sciences. 35, 95-105. (in Japanese with English summary)

[8] Oda, K., Yamazaki, K., Miura, H., Shibasaki, H., and Kikuchi, T. Neuropathol Appl Neurobiol, in press.

[9] Yamazaki, K., Wakasugi, N., Sakakibara, A., and Tomita, T. (1988). Exp. Anim, 37, 195-199.

[10] Yamazaki, K., Wakasugi, N., Tomita, T., Kikuchi, T., Mukoyama, M., and Ando, K. (1988). Proc. Soc. Exp. Biol Med, 187, 209-215.

[11] Yamazaki, K., Kobayashi, A., Kumazawa, A., Wakabayashi, T., and Kikuchi, T. (1991). Biomed Res, 12, $143-148$.

[12] Wall, P. D. (1979). Brain 101, 1-18. 


\section{Gracile axonal dystrophy (GAD) \\ マウスに関する行動学的研究 \\ 山崎一斗・中澤隆弘・松永学・熊澤彰良 \\ 金子武稔・若林庸夫 \\ エーザイ株式会社筑波研究所}

Tail-flick test及び rotarod testを用いて， $5 \sim 11$ 週龄の神経変性ミュータント gracile axonal dystrophy (GAD) マウスに関する行動学的検討を行った。Tailflick testにより， 6 および 8 週齢の GAD 雌マウス にわずかながら tail-flick latency の有意な減少が認 められた。これは痛覚を制御していると考えられている 後索線維の側枝の変性に関与している可能性がある。 Rotarod test では, rotarod performance time の有 意な減少が GAD 雄マウスで 5 週龄から，GAD 雌マウ
スで 6 週龄から累積 $\chi^{2}$ 検定法により示された。これは rotarod test が GAD マウスの感覚性失調を $5 \sim 6$ 週齢 から検出できることを示唂する。GAD マウスの rotarod performance timeは 9 週㱓以後急速に低下したが，こ れは GAD マウスの運動麻痺の進行と一致する。今回 の検討により, rotarod test は GAD マウスの早期の客 観的選抜，あるいは GAD マウスに対する運動失調， 運動麻瘦の薬物評価に応用できることが示唆された。 